\title{
Trade-offs in pastoral governance in Norway: Challenges for biodiversity and adaptation
}

\author{
Camilla Risvoll $^{1 *}$, Gunn Elin Fedreheim² and Diego Galafassi ${ }^{3}$
}

\begin{abstract}
Norway is committed to the two-fold policy objective of preserving biodiversity and maintaining traditional local livelihoods. This creates management dilemmas with the potential to undermine the legitimacy of both national and international policies. In this article, we take a social-ecological perspective to highlight how these two policy objectives are linked and interdependent and, therefore, subjected to complex dynamics between institutions and ecosystems. We use a case study in northern Norway to discuss trade-offs in the implementation of the two-fold conservation objectives.

Based on interviews, a focus group meeting with 16 reindeer herders and stakeholders and participant observations during a grazing committee meeting, we identified that ecological dynamics between carnivores, sheep and grassland patterns are central to this trade-off. We demonstrate how current governance instruments in carnivore management do not address the spatial dynamics of carnivores leading to a perceived conflict between environmentalist groups and farmers around questions of carnivore protection and sheep killings by carnivores. Fragmentation in the multi-layered governance system prevents ongoing dialogue among various actors, thereby enhancing antagonisms while reducing the likelihood of the emergence and implementation of adaptation measures and practices.
\end{abstract}

Keywords: Multi-level governance, Trade-offs, Adaptive capacity, Biodiversity, Carnivores

\section{Background}

Curbing global biodiversity loss sits among the most pressing issues of our time (Rockström et al. 2009; Young et al. 2010; Butchart et al. 2010). Nature conservation and pastoralism are often deemed incompatible (Young et al. 2005; Skogen and Thrane 2008; Heikkinen et al. 2012), and conflicts often arise from the restrictions that biodiversity conservation imposes upon land use and pastoralists' livelihoods (Heikkinen et al. 2012; Young et al. 2005).

International conventions regarding nature and biodiversity protection have gained considerable influence over national conservation policies, and the Norwegian government has changed its involvement in carnivore governance, from state policies supporting eradication of

\footnotetext{
* Correspondence: camillarisvoll@gmail.com

${ }^{1}$ Faculty of Social Sciences, University of Nordland/ Nordland Research

Institute, Universitetsaleen 11, Mail Box 1490, 8049 Bodø, Norway

Full list of author information is available at the end of the article
}

carnivores (wolf, brown bear, wolverine, lynx, golden eagle) throughout the 18th, 19th and 20th century to policies in the latter part of 21st century that aim to conserve biodiversity and thereby large carnivores (Heikkinen et al. 2011). Reindeer herding and sheep breeding have traditionally been important for rural districts in Norway, and the Norwegian government is committed to also protect the rights and livelihoods of the local people in these regions.

Norwegian commitment towards protecting biodiversity (here focused on large carnivores) on the one hand and protecting local and indigenous peoples' rights and culture on the other create management dilemmas with the potential to undermine the legitimacy of both national and international policies (Sandberg 1999; Swenson and Andren 2005). Norway has explicit policy goals aimed at fulfilling the "two-fold aim" of contemporarily protecting biodiversity and local livelihoods.
焦 Springer

C 2016 Risvoll et al. Open Access This article is distributed under the terms of the Creative Commons Attribution 4.0 International License (http://creativecommons.org/licenses/by/4.0/), which permits unrestricted use, distribution, and reproduction in any medium, provided you give appropriate credit to the original author(s) and the source, provide a link to the Creative Commons license, and indicate if changes were made. 
Although desirable, this "win-win" policy objective can be contradictory at the local level.

This tendency to search for win-win situations while disregarding trade-offs is common in environmental policy design (McShane et al. 2011). However, policy interventions in intertwined social-ecological systems are more likely to generate trade-offs than win-wins. Tradeoffs occur when management decisions enhances one aspect of the system to the detriment of another aspect (Daw et al. 2015; Rodríguez et al. 2006). Trade-offs can emerge from complex interlinkages between biophysical and social processes across scales. What appears as a trade-off from one perspective might be seen as a synergy from another perspective. Deliberating about trade-offs is a central dimension of governance, and disregarding trade-offs can give rise to conflicts between management objectives and can often blur the complex dynamics between biophysical characteristics and local culture and livelihoods leading to less responsiveness from the governance system (Brown et al. 2001). This can eventually reduce the overall social-ecological resilience (Plummer and Armitage 2010). On the other hand, attention to underlying dynamics of trade-offs might reveal deeper causes for conflicts and support the search for possible synergies in management objectives (Howe et al. 2014; Sandberg 1999).

In this paper, we explore the dilemmas unfolding from the two-fold policy objective stated in the Carnivore Agreement (Rovdyrforliket). This agreement constitutes a policy arrangement for ensuring sustainable carnivore populations and sustaining active and viable pastoral communities. The close interaction between livestock and carnivores complicates the win-win objective: 130,000 sheep and 80,000 reindeer disappear every season, and owners receive economic compensation based on losses to large carnivores for 35,000 sheep and 65,000 reindeers (Directorate for Nature Management 2011). In 2008, the government-funded compensation was almost 22,500,000 USD nationally (Directorate for Nature Management 2011).

We investigate how a trade-off between these goals is manifested at the local level in Nordland, northern Norway, and examine the responses of the governance system at multiple levels. Nordland borders Sweden along a north-south gradient at around $500 \mathrm{~km}$ at the eastern side of the county. Carnivores roam vast areas and migrate across the border between Nordland, Norway and Sweden when habitats are available (Swenson and Andren 2005). Carnivore density in Sweden, particularly wolverines and brown bears, is high compared with Norway. Thus, carnivore populations in Norway are highly dependent on the traditionally much larger Swedish carnivore populations (Gangaas et al. 2013). Today's governance of carnivores in Sweden resembles the two-fold aim of the Norwegian policy to ensure sustainable populations while at the same time safeguard livestock production (Naturvårdsverket 2015). Even though we acknowledge the fact that Swedish carnivore policies influence the Norwegian stocks, we will not investigate further the Swedish policies. This paper deals with the Norwegian setting and leaves the Swedish policies in the background.

\section{Methods and study area}

The analysis is based on several different data sources: public documents, reports, recordings from meetings, observations in meetings and interviews. With regard to secondary data, we used local and national newspaper clippings and Internet sites. Reports for production subsidies (the Norwegian direct payment base) were publicly available on the Norwegian Agriculture Agency web pages (www.slf.dep.no). We gathered statistical information and maps from Rovbasen and Rovviltportalen (Norwegian Environment Agency 2014).

We conducted interviews in the period from 2011 to 2013 with 17 reindeer herders and 13 sheep farmers from the area. We conducted one group interview with four reindeer herders in autumn of 2012 and one followup interview with a herder. The other interviews noted above were individual interviews with herders or farmers. Moreover, we conducted a focus group interview in June 2011 with 16 people (eight reindeer owners, two tourism operators, three from the public authorities, two national park guides and one from the Norwegian Nature Inspectorate). Nine interviews with relevant actors and agencies at the local and regional levels were conducted during 2011 to 2013, such as the Regional Carnivore Committee (RCC), agricultural advisors, environmental government agencies and the Norwegian Nature Inspectorate (NNI). We carried out three followup interviews on topics that have emerged in the media and at meetings. These interviews helped us to fill in identified gaps after conducting an initial analysis. We were also observers at relevant meetings and seminars with pastoralists, pastoralists' organizations and local government's representatives.

We transcribed all interviews and analysed them using the text analysis software MaxQda. We performed field work in the autumn of 2011, 2012 and summer of 2013 (see Table 1).

Our empirical sources focus on sheep and reindeer pasture communities in the county of Nordland, Norway (Figure 1).

\section{Multi-level governance of mountain rangelands}

In this section, we outline the historical development of pastoralist practices and the evolution of governance system that deals with carnivores and traditional local 
Table 1 Overview of methods

\begin{tabular}{|c|c|c|c|c|c|c|}
\hline \multirow[t]{2}{*}{ Informants } & \multicolumn{5}{|c|}{ Description of methods } & \multirow[t]{2}{*}{ Timeframe } \\
\hline & $\begin{array}{l}\text { Semi-structured } \\
\text { interviews }\end{array}$ & $\begin{array}{l}\text { Focus group } \\
\text { interviews }\end{array}$ & $\begin{array}{l}\text { Group } \\
\text { interview }\end{array}$ & $\begin{array}{l}\text { Follow-up } \\
\text { interview }\end{array}$ & $\begin{array}{l}\text { Participant } \\
\text { observation }\end{array}$ & \\
\hline Herding districts (reindeer herders) & 17 & 8 attended & 4 & 1 & & $\begin{array}{l}2011 \text { to } 2013 \\
\text { follow-up } 2013\end{array}$ \\
\hline $\begin{array}{l}\text { Sheep farmers (Fauske, Saltdal and } \\
\text { Sørfold municipalities) }\end{array}$ & 13 & & & & $\begin{array}{l}\text { Grazing committee } \\
\text { meeting, ad hoc } \\
\text { meeting }\end{array}$ & \\
\hline $\begin{array}{l}\text { Other key stakeholders (Regional } \\
\text { Carnivore Committee, local agricultural } \\
\text { officers, National State Forest, Reindeer } \\
\text { Administration, Nature Inspectorate }\end{array}$ & 9 & $\begin{array}{l}8 \text { stakeholders } \\
\text { attended }\end{array}$ & & 3 & & 2011 to 2013 \\
\hline Total & 39 & 16 & 4 & 4 & & \\
\hline
\end{tabular}

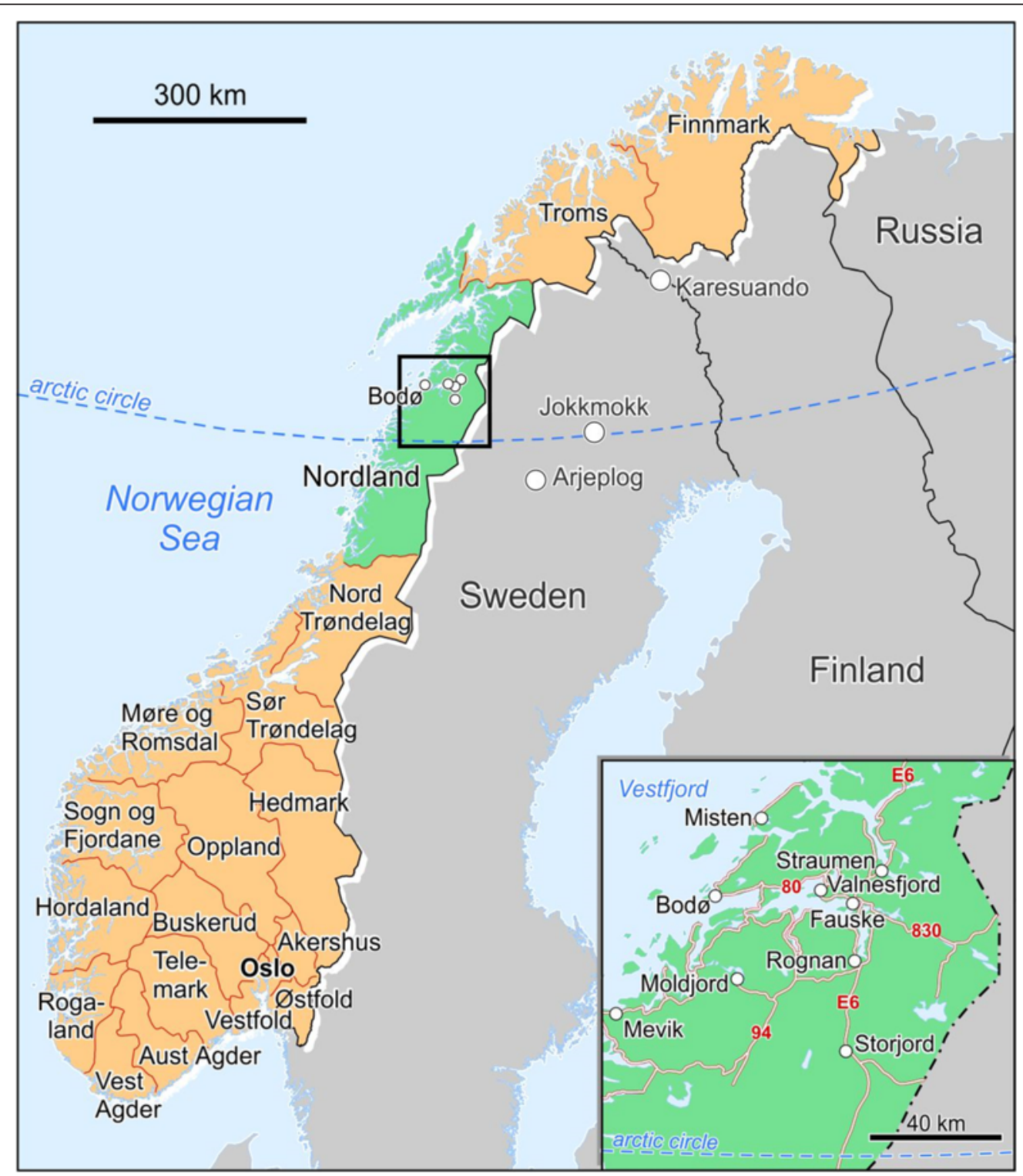

Figure 1 Salten region in Nordland, northern Norway (Source: Marc Girard, Université de Montréal) 
livelihoods. The mountain rangelands (utmark) comprise resource systems where native wild animals and domestic animals coexist and collective dilemmas unfold (Ostrom 2005, 2007a, 2009; Aligica 2014). Actions carried out by pastoralists, e.g. in regard to husbandry, have bearings for the social-ecological system as a whole.

\section{Pastoral field}

Most of the pastures for reindeer and free-ranging sheep in Norway consist of harsh mountain ranges that are mostly common lands. Reindeer herding is area intensive, and approximately $40 \%$ of Norway's land area is used for grazing (Landbruksdirektoratet 2014). These mountain ranges are mostly impossible to cultivate, but they are suitable for grazing animals due to their rich soil surface and vegetation (Bjørkhaug and Rønningen 2013). Pastoralists have been part of an ongoing modernization and rationalization process of animal husbandry with increased mechanization, which has made more extensive pasturing possible (Jaren and Løvstad 2001). One important reason for the long rationalization process of animal husbandry was the persistent policies since 1728 for "the eradication of all useless and harmful" wildlife in order to enable increased livestock production (Sandberg 1999). Due to the long period where large carnivores were almost absent from the Norwegian mountains (1900 to 1975), farmers have optimized husbandry for livestock operations with minimal labour input in grazing the sheep on summer pastures and in protecting their livestock against large carnivore attacks.

Ingold (1980) distinguished between modes of production in terms of pastoralism, ranching and hunting. We categorize both sheep and reindeer husbandry in Norway as pastoralism, because both sectors have collective access to pastures in the communal rangelands. Conversely, ranching usually refers to grazing on private land. Herding and husbandry are two related but different ways of referring to reindeer herders' or reindeer owners' practices. Both terms are applied in this article, depending on the context. Herding refers to moving and tending the reindeer in the pastures, whereas husbandry is a broader term and may include all activities related to reindeer and its products, e.g. yard work, slaughtering and breeding strategies (Berg 2000). The studied herding districts share an east-west migratory herding pattern (Skogseid 1997; Sande 2010), and both intensive and a more extensive herding practice are carried out in the studied region (Sande 2010). Intensive herding is usually characterized by continuous tending of the herd, which also makes the herd tamer, while extensive herding is characterized by less contact with the herd.

The trend since the 1970s is for structure rationalization, with an emphasis on larger and fewer farm units with increased number of animals (Jaren and Løvstad 2001). In the region of study where carnivore density is relatively high, the number of sheep has increased during the past 20 years, whereas the number of farmers has decreased significantly ${ }^{1}$.

The agricultural sector in Norway is closely linked to the political system and highly politicized (Bjørkhaug and Rønningen 2013). Generally, the Norwegian environmental bureaucracy has been challenged about preserving biodiversity by international pressure, along with requests for local participation and involvement from the local level. This has increased the complexity across governance levels (Fangel and Gundersen 2012). Actors within the pastoral sectors (Table 2) interact across governmental departments regarding carnivore management. Agricultural policy has mostly been framed through annual agricultural settlements (i.e. the annual Whitepaper (Jordbruksavtalen)) (see, e.g. Kristoffersen 2015).

Sámi people have hunted wild reindeer for generations, but since the 16th to 17th centuries, a shift occurred towards herding semi-domesticated reindeer (Vorren 1978; Berg et al. 2003; Bjørklund 2013; Risvoll et al. 2014). Today, approximately 18,200 domesticated reindeer exist in Nordland across 12 reindeer herding districts. In addition, Swedish reindeer graze in Norway along the border regions and according to the mutual agreement between Norway and Sweden (Reindriftkonvensjonen 2010). Reindeer herding is regulated by the Reindeer Herding Act (LOV-1972-06-09-31 (1972)), and only Sámi people are legally permitted to own reindeer in northern Norway (Reindeer Herding website 2015). The right to own reindeer is connected to the right to graze, and the latter is strictly regulated according to seasons, for instance. There are three active administrative levels in reindeer governance, as Table 3 illustrates.

\section{Carnivores}

Large carnivores that historically inhabited mountain regions were almost eradicated by the end of the 19th century and the beginning of the 20th century (Blekesaune and Stræte 1997). International conventions have gained considerable influence over national conservation policies (Heikkinen et al. 2011), starting with protecting the brown bear during the 1960s. This development occurred at a time when increased environmental focus and involvement was present among the Norwegian population (Fangel and Gundersen 2012). Wolverine protection came later, in 1971 in southern Norway and in 1982 in northern Norway. Norway ratified the Bern Convention in 1986, which implies a commitment to safeguard sustainable carnivore populations in Norway (Norwegian Environment Agency 2014). This commitment is in line with the increasing international 
Table 2 Responsible/influential agencies in sheep governance and management

\begin{tabular}{|c|c|c|}
\hline Level & Responsible agency & Areas of responsibility \\
\hline International & Food and Agricultural Organization (FAO) & $\begin{array}{l}\text { - Guidelines for responsible animal husbandry } \\
\text { - Support members to ensure that people have access to } \\
\text { enough high-quality food }\end{array}$ \\
\hline \multirow[t]{4}{*}{ State } & Ministry of Agriculture and Food & $\begin{array}{l}\text { - Policy development } \\
\text { - Annual agricultural settlement }\end{array}$ \\
\hline & Norwegian Agricultural Authority & - Executive work \\
\hline & Norwegian Food Safety Authority & - Inspection on husbandry and transport \\
\hline & Nortura $^{a}$ & - Market regulation \\
\hline Regional & Agricultural division, Regional County Principal & $\begin{array}{l}\text { - Advisor for the Municipalities } \\
\text { - Regulatory agency } \\
\text { - Collaborate with other regional services and organizations } \\
\text { for industrial development }\end{array}$ \\
\hline \multirow[t]{2}{*}{ Local } & Agricultural office, Municipality & $\begin{array}{l}\text { - Managing internal affairs } \\
\text { - Deciding on land-use plans } \\
\text { - Facilitate farmers }\end{array}$ \\
\hline & Farming household & $\begin{array}{l}\text { - Practical management } \\
\text { - Participate in organizations, boards and meetings }\end{array}$ \\
\hline
\end{tabular}

${ }^{a}$ Nortura is the main Norwegian agricultural cooperative that operates slaughterhouses and processing plants related to meat and eggs (Nortura's webpage: www.nortura.no)

focus on protecting endangered species and preserving biodiversity, which also has been implemented in the legislation of other northern countries (Sandberg 1999). This protection strategy, together with reforestation and growth in wild herbivores, has resulted in a dramatic increase of large carnivores in northern Europe over the past years. Thus, the emerging picture is a conservation success story, in which the large carnivores have shown an ability to survive in human-dominated landscapes (Chapron et al. 2014).

Today, carnivores are regulated by the Wildlife Act (LOV-1981-05-29 nr 38 (1981)) and the Nature Diversity Act (LOV-2014-06-20-50 (2014)). The former regulates when, where and how hunting might be undertaken; the latter specifies conditions and precautions. The carnivore policies also build on

Table 3 Administrative levels and areas of responsibility in reindeer governance and management (adapted from Fedreheim 2013)

\begin{tabular}{|c|c|c|}
\hline Level & Responsible agency & Areas of responsibility \\
\hline International & $\begin{array}{l}\text { International Labour Organization (ILO) Convention } \\
\text { No. } 169 \text { on Indigenous and Tribal Peoples }\end{array}$ & $\begin{array}{l}\text { - Safeguarding the rights of the persons, institutions, property, } \\
\text { labour, cultures and environment of the Sámi people }\end{array}$ \\
\hline \multirow[t]{3}{*}{ State } & Ministry of Agriculture and Food & $\begin{array}{l}\text { - Policy development } \\
\text { - Reindeer Herding Act } \\
\text { - Reindeer Herding Agreement } \\
\text { - Appeals court for the Norwegian Reindeer Husbandry Board }\end{array}$ \\
\hline & Norwegian Agriculture Agency ${ }^{b}$ & $\begin{array}{l}\text { - Executive work } \\
\text { - Secretariat for the Norwegian Reindeer Husbandry Board }\end{array}$ \\
\hline & Norwegian Reindeer Husbandry Board ${ }^{c}$ & - Appeals court for decisions taken in the reindeer departments \\
\hline Regional & County Governors' Department of Agriculture and Food ${ }^{d}$ & $\begin{array}{l}\text { - Control the Siidas and act as expert councils over controversies } \\
\text { - Give exemptions from grazing rules } \\
\text { - Approve husbandry rules, decide grazing times } \\
\text { - Consider subsidy applications }\end{array}$ \\
\hline \multirow[t]{2}{*}{ Local } & 89 reindeer districts across the country & $\begin{array}{l}\text { - Manage internal affairs } \\
\text { - Decide on land-use plans } \\
\text { - Predict reindeer numbers }\end{array}$ \\
\hline & Siida with Siida-shares & $\begin{array}{l}\text { - Practical management } \\
\text { - Participate in organizations, boards and meetings }\end{array}$ \\
\hline
\end{tabular}

${ }^{\mathrm{a}}$ Reindriftsstyret

${ }^{b}$ Landbruksdirektoratet. Replaced the former Norwegian Reindeer Husbandry Administration from July 1st, 2014

'Its seven members are appointed by the Ministry (four) and the Sámi Parliament (three)

${ }^{d}$ New from January 1st 2014. Then six reindeer herding area boards were removed, and their tasks were given to the County Governor's Department

of Agriculture

${ }^{\mathrm{e}}$ One or several groups of reindeer owners, understood as families. A person holds a siida-share 
government reports (St.meld.nr. 27 (1991-1992), St.meld.nr. 35 (1996-1997), St.meld.nr.15 (2003-2004)), on discussions related to this and on Parliament's settlement of June 17, 2011, commonly referred to as "Rovdyrforliket" (the Carnivore Agreement) (Stortinget 2011: Document 8:163 S (2010-2011)). In recent years, research has intensified on the consequences of the return of large carnivores to Norway. Recent studies indicate that there are cleavages in the Norwegian population regarding perceptions and views regarding large carnivores, and while not dominant, support for large carnivores exist in many rural communities (e.g. Skuland and Skogen 2014; Skogen 2014).

Various actors are involved in predator management in Norway (see Table 4). The eight RCCs are responsible for implementing the national policy. These boards have five or six members each appointed by the Ministry of Climate and Environment after being nominated by the County Council/Sámi Parliament (FOR 2005-03-18 nr 242). One of the reasons for choosing this solution was to ensure local management of carnivores and thus to lower the conflict level related to carnivore governance. Further, it is argued that subsidiarity is important at the regional level since decisions reached here reflect implementation of the national policy. Hence, a politically appointed regional carnivore committee is a continuation of the politically comprised agencies. Ecological knowledge is already expected to be interwoven at the regional level, since it serves as a foundation for earlier work. An overview of the administrative levels in Norwegian carnivore governance is presented in Table 4 .

\section{The Carnivore Agreement (Rovdyrforliket 2011)}

The preceding outline of the Norwegian carnivore governance comprises the backdrop for the Carnivore Agreement (2011), which supports the "two-fold objective" consisting of ensuring sustainable carnivore populations while simultaneously sustaining active and viable pastoral communities. This two-fold objective has been the basic principle in each of the three White papers regarding carnivore governance (St.meld.nr. 27 (1991-92), St.meld.nr. 35 (1996-97) and St.meld.nr.15 (2003-2004)) and is also the main principle of Norway's carnivore governance (Fangel and Gundersen 2012).

All political parties in the Norwegian parliament (Stortinget) settled on the Carnivore Agreement in 2011. It emphasizes biological and ecological knowledge as a major foundation for carnivore governance in order to obtain desired population estimates. The document decides upon sustainable size of population for each

Table 4 Norwegian administrative levels and areas of responsibility in large carnivore governance (adapted from Fedreheim 2013)

\begin{tabular}{|c|c|c|}
\hline Level & Responsible agency & Areas of competence/responsibility \\
\hline \multirow[t]{2}{*}{ International } & Bern Convention & • Ensures sustainable carnivore populations \\
\hline & & $\begin{array}{l}\text { - Conserve biological diversity } \\
\text { - Ensures sustainable use of biological diversity's components }\end{array}$ \\
\hline \multirow[t]{3}{*}{ State } & Ministry of Climate and Environment & $\begin{array}{l}\text { - Has overall responsibility for wildlife } \\
\text { - Appoints members to the Regional Carnivore Management Boards } \\
\text { - Serves as Appeals Court for the Regional Carnivore Management Boards }\end{array}$ \\
\hline & Norwegian Environment Agency & $\begin{array}{l}\text { - Performs bureaucratic work related to the Wildlife Act } \\
\text { - Gathers knowledge and information about wildlife } \\
\text { - Serves as Appeals Court for the County Governor }\end{array}$ \\
\hline & State Nature Inspectorate & $\begin{array}{l}\text { - Executive field branch } \\
\text { - Assists livestock owners in gathering documentation } \\
\text { - Prevents and stops environmental criminality } \\
\text { - Supervises the stock of carnivores } \\
\text { - Carries out measures initiated by the Norwegian Environment Agency }\end{array}$ \\
\hline \multirow[t]{2}{*}{ Regional } & County Governor & $\begin{array}{l}\text { - Manages Golden Eagles } \\
\text { - Performs damage prevention efforts related to the Golden Eagle } \\
\text { - Decides on quotas and licensed hunting on all large carnivores } \\
\text { - Guides (and acts as the secretariat for) the Regional Carnivore } \\
\text { Management Boards }\end{array}$ \\
\hline & Regional Carnivore Committees ${ }^{a}$ & $\begin{array}{l}\text { - Implementing the national policy in their regions } \\
\text { - Set the yearly quota for hunting lynx, wolverines and brown bear } \\
\text { - Set the yearly number of lynx hunters and licensed hunters of } \\
\text { wolverines and brown bears } \\
\text { - Develop detailed guidelines for use of funds } \\
\text { - Develop a management plan based on the national targets, including } \\
\text { area differentiation plan }\end{array}$ \\
\hline Local & Municipality & - Manage wild herbivores \\
\hline
\end{tabular}

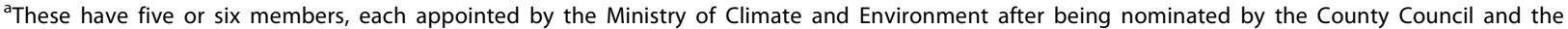
Sámi parliament 
species. A main objective with this agreement is to reduce the level of conflict between the different interests by strengthening the capacity and competence of the agencies dealing with carnivore management around (1) reporting and registration of carnivores and (2) preventive actions through the Regional Carnivore Committees and local hunting teams. The document also clarifies regulations around hunting licences and population goals for the different carnivores. It states that local actors, particularly actors from the pastoral sectors, should be involved in population registration and should also be represented in local hunting teams. Furthermore, it emphasizes that knowledge of carnivores' behaviour and habitats is to be communicated to the local communities (Parliament's Document Nr. 8:163 S (2010-2011)).

This policy instrument does not explicitly acknowledge potential trade-offs that might emerge from trying to reach two different policy objectives. The responsibility for carnivore management is handed from central to local authorities (Fangel and Gundersen 2012) by decentralizing the carnivore management to the appointed RCCs at the regional level. The RCCs' main task is to create the management plan for carnivores in their region, and they have the possibility to geographically differentiate the management through differentiated zones for carnivores and domestic livestock. Despite this scope of action, Sandström et al. (2009) found that interaction and dialogue between parties within carnivore governance have succeeded to a greater extent at the national and partly the regional level. The dialogue has been less successful locally, which contributes to a lack of legitimacy at the local level (Fangel and Gundersen 2012), and will be discussed below.

\section{Results}

Pasture dynamics in a "carnivore-cultural landscape"

To begin with, we identify a mismatch between the management of the carnivores and their ecological dynamics and spatial distribution. Government officials and many farmers emphasized that large carnivores naturally live in areas that are allocated for domestic animals as they (wolverines and brown bears, in particular) continuously migrate across the border between Norway and Sweden. For example, most of the municipality of Saltdal is a prioritized pasture area. Core carnivore areas surround pasture areas, and Figure 2 shows the zoning of the brown bear (shaded area). The dotted points in Figure 2 represent brown bear locations (based on GPS data). There is a clear mismatch between the zoning of brown bears and their actual natural habitats.

Government officials across levels point out how zoning and area differentiation in the carnivore management plan are unrealistic to follow. Particularly challenging are the prospects passed on to pastoralists about specific prioritized pasture areas.

Swedish legislation allows relatively extensive bear hunting, and the bear population is decreasing (Swenson et al. 2010). This strategy has implications for the Norwegian bear population, and the likelihood of females settling in Norway is reduced. Males, on the other hand, which predate heavily on sheep, have a much larger home range and regularly roam over the border to Norway (Swenson and Kindberg 2011). Nordland's geography, with its long narrow strip of land bordering on Sweden, makes the cross-border migration impossible to prevent. Nordland County has its bear population level on one family group; however, this level is not likely to be reached with the extensive culling on the Swedish side. Thus, area differentiations for brown bears will remain challenging in Nordland as long as the goal of one family group is not reached. Despite this dependence on Swedish governance and ecosystem dynamics, government officials in Nordland admit that collaboration is limited at the regional level between the two countries relating to carnivore governance. This was perceived by the government official to be a consequence of the very different management regimes between the two countries.

Government officials further note that a major difficulty with this area differentiation is that the map is highly fragmented. This fragmented zoning is difficult to manage as carnivores roam over very large areas, and within one day they can cross several regions that are all prioritized for grazing animals and for carnivores (see Figure 3). There is no clear pattern for where the farms are located, and the steep topography in Nordland and the close vicinity to Sweden determine much of the farming settlements.

According to a RCC representative, their criteria for deciding upon areas prioritized for carnivores are based upon sheep farmers' and reindeer herders' geographical location. They plotted down the areas with a high density of farmers and prioritized them for sheep, and reindeer herders' main pastures were the basis for prioritized reindeer grazing areas. Considerations and analysis regarding ecosystem characteristics and carnivore dynamics were not part of this area differentiation. The RCC representative noted:

\section{We know that the carnivores follow their potential food sources, so the barrier to cull carnivores in areas prioritized for grazing livestock should be low. We cannot move the farms (Individual interview with key stakeholder)}

This was in line with several farmers' perceptions regarding zoning and moving grazing animals to different locations. One farmer expressed this opinion: 


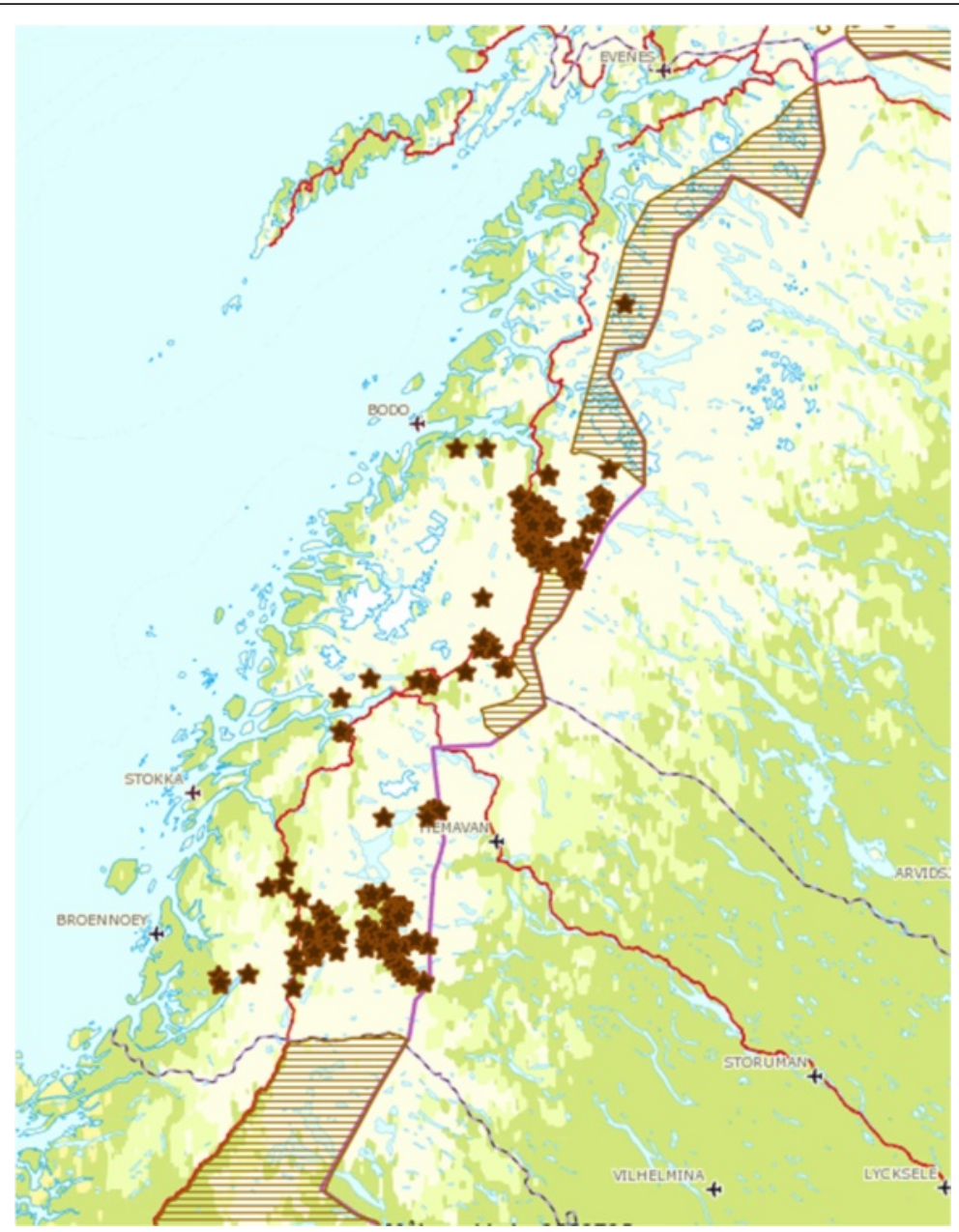

Figure 2 DNA hits on brown bears in Nordland 2006 to 2014. Shaded area is prioritized bear habitat. (Source: Vegar Pedersen SNO/Rovbase)

Moving the sheep to an area that has less carnivores is a poor solution as we only bring the problem to this region. Carnivores move to where the food sources are, and if there is no food in an area the carnivore will not remain there (Individual interview with farmer)

The County Governor was hesitant to implement the RCC's suggested area zoning for bears before the carnivore management plan was ratified (NRK Nordland 2010). They argued that the areas suggested were too narrow and small; however, the RCC in Nordland ratified this plan in 2011. Interviews with government officials revealed their concern with the carnivore management plan because they claimed that the carnivore zones on the map do not reflect the ecosystem dynamics in reality. Follow-up interviews with government officials at the regional level revealed that particularly the Norwegian Environment Agency (NEA) but also the County Governor in Nordland and the Ministry of
Climate and Environment (MCE) argued for a revision of the carnivore management plan. An official from NNI (SNO) noted that the management plan is meant to bring about predictability for pastoralists, and in accordance with the National Carnivore Agreement and the Regional Management Plan, any bears coming into the areas prioritized for livestock should be culled. However, this is very problematic as long as the population goal for the County as a whole is not fulfilled. The official further noted that conflict is difficult to prevent, as it is likely that, for example, the first family group of bears will establish in an area that is prioritized for domestic livestock.

Regional governmental officers noted that the RCC has so far not been willing to open up for changes regarding the area zoning, as they want the focus on maintaining grazing areas. The government officer further noted that a problem with today's area zoning is that hardly any difference exists as to whether a sheep farmer is inside or outside a certain zone. With 


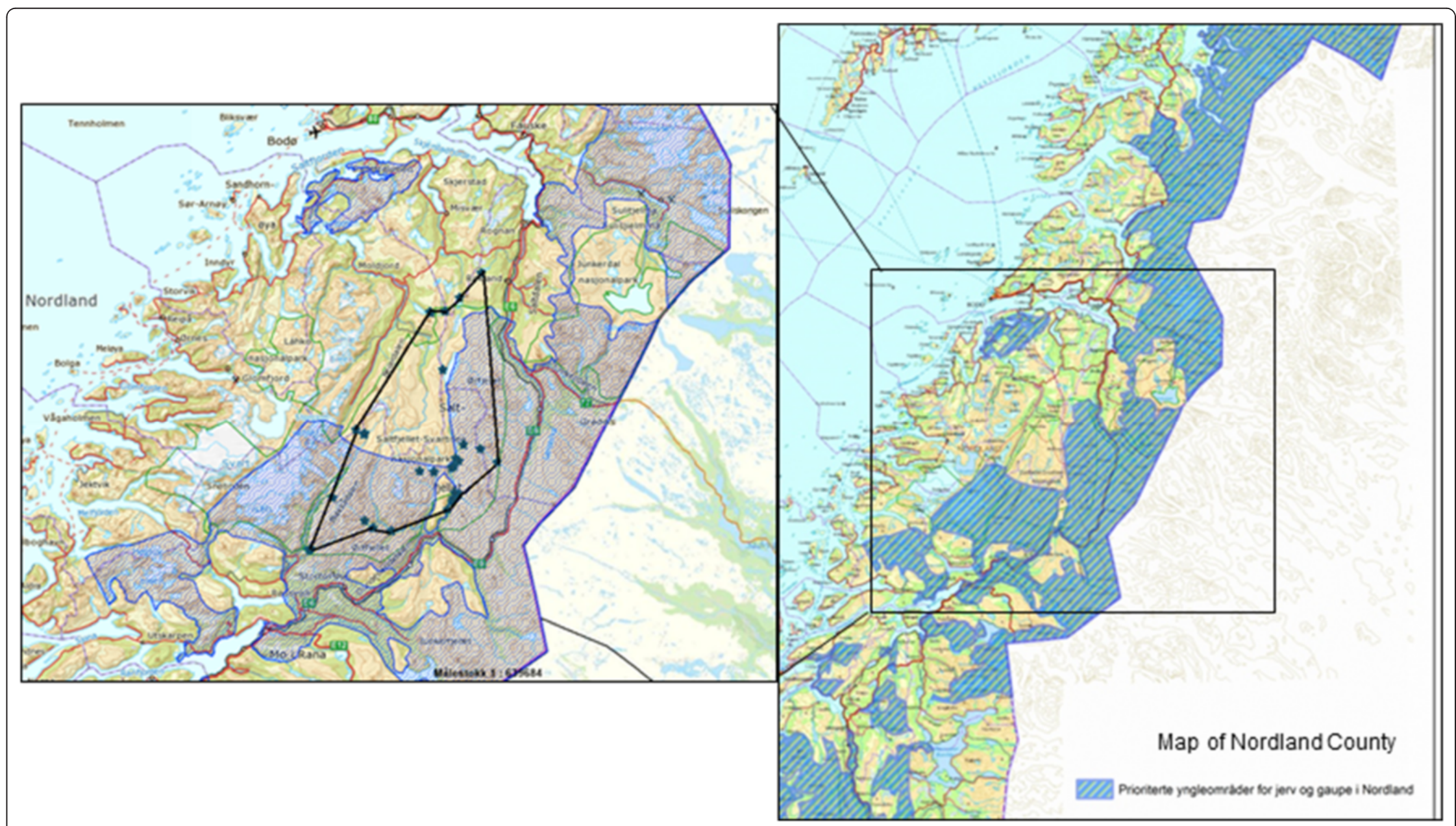

Figure 3 Map (left) showing DNA hits for one wolverine. Black coloured line between stars showing minimum habitat for this wolverine. Shaded areas are prioritized for wolverines and lynx

(Adapted from Vegar Pedersen SNO/Rovbase 2015) 
new zoning, where carnivores' biology is included, it may be harder for farmers in areas where carnivores are abundant but more predictable in areas with less carnivore pressure. For those farmers with high carnivore pressure (in carnivore zones), shifting to different farming methods may provide a potential option. For those in prioritized grazing zones, the threshold for culling carnivores will be lower, and they may experience more predictability. The government officer emphasized that some compromises must be made in area zoning, which is not the reality with today's management plan for carnivores. Regarding today's area zoning, the officer expressed his opinion like this:

\section{The existing area zoning has created certain} expectations for the pastoralists that are impossible to meet with today's available instruments and guidelines (Individual interview with regional government official)

The officer also acknowledged that Nordland is probably the hardest county in which to create area zones, because of the topography and fragmented landscape.

An RCC representative pointed to the difficulties in area zoning and noted that they followed the advice from the NEA on clearer divides between the different zones when they decided upon today's management plan. When they emphasized such clear divides, e.g. including reindeers' calving land inside zones prioritized for livestock, they met opposition from the NEA saying that ecosystem dynamics had been neglected. The RCC representative noted:

\section{It is frustrating that we earlier were accused for not} making the management plan clear and explicit enough. When we then try to make clear divides between the different zones, this is not sufficient either. It is difficult to achieve the twofold aim, and there are many considerations to take (Individual interview)

A common aim presented in the Carnivore Agreement (2011) is that animal losses in the pastoralist sectors must be reduced. It states: "In prioritized grazing areas, the carnivores that do damage on livestock are to be culled rapidly" (Parliament's Document Nr. 8:163 S (2010-2011), based on authors' own translation). Such a goal is difficult to achieve because of carnivores' extensive habitat, according to government officials.

\section{Pastoralists' adaptation in pastures}

Pastoralists have tried a myriad of strategies to prevent losses to carnivores. Governmental funding is available to varying degrees for those implementing loss-mitigating strategies. For reindeer husbandry, new practices consist of GPS-tracing the reindeer to call out when suspicious roaming is observed (Eilertsen 2008), keeping animals fenced in yards throughout winter, supplementary feeding and changing to coastal pastures. Some reindeer herders have tended their herd in the mountains all throughout winter and note that carnivore losses decreased due to better herd control. Sheep farmers have tried delayed release of the sheep to mountain pastures, earlier muster in autumn, trying different sheep breeds, GPS-tracing, fencing, watch dogs and llamas and intensified shepherding (see Risvoll 2015, for more detail). Meanwhile, pastoralists perceive these strategies as relatively unproductive, one government officer noted:

Pastoralists have tried many things to avoid losses but I am not sure that they have tried enough. For instance if we ask if they have tried early muster in autumn one farmer will say yes, but then the neighbor might not have done the same. There is a problem of coordination. I am sure more can be done in regards to the available incentives in order to reduce losses (Individual interview (see Table 1))

\section{Government instruments in carnivore management}

A main management strategy from the RCC is to focus on getting the carnivore numbers down by obtaining more hunting licences. One government official noted that when wolverines are culled, the empty home range soon fills again. This supports the view by Odden et al. (2014) that points to the local effect of culling a lynx as only very temporary in areas where lynx are continuously present, as the home range will soon be replaced by new lynxes. Hunting large carnivores is challenging, according to local and regional government officials, and an important measure for success is to train hunters. The rules concerning hunting are perceived as too rigid by hunters, the RCC and several pastoralists, as they make e.g. wolverine and lynx culling a very difficult task. One government official noted:

License hunting of wolverines is emphasized as an important instrument in the Carnivore Agreement (2011). Then the hunters point out the difficulties in carrying out hunting, for instance not being able to use motorized transport to check upon pens faraway, not being allowed to use web cameras or dogs, as well as the set hunting times. These factors are impeded by national regulations as the white paper on hunting does not open for such activities. This creates problems and if there is a political wish to cull more wolverines, well then the Norwegian regulations on hunting must be altered (Individual interview)

However, a trial initiated by the government has recently relaxed some of the rigid rules regarding hunting, for instance, by opening up for use of, e.g. web cameras, and snowmobiles for transport and checking on pens. 
Nevertheless, hunting large carnivores during the summer season when particularly sheep losses are large is very difficult with the tools available today (e.g., in Trondsen 06.08.2015; Våg and Walling 2015).

An important strategy by the government to minimize conflicts is to compensate pastoralists. This is a considerable part of pastoralists' income in high-pressure areas for carnivores. However, sheep farmers note that they usually only have between $40 \%$ and $50 \%$ of their animal losses compensated, since this is the number verified by the officials. The Norwegian Institute for Nature Research recently published a thematic number on lynx predation on sheep, wherein they recommend a compensation scheme that is to a larger extent founded on objective mapping of carnivore risk and knowledge of the predation frequency on sheep in different landscapes (Odden et al. 2014). However, both sheep farmers and reindeer herders in Norway have recently rejected such suggested changes. They are sceptical about the carnivore population goals set forth by the government and do not feel that they have been heard in regard to their observations of carnivore numbers in the area.

\section{Local perceptions of carnivore management}

The local governments' representatives perceive their collaboration with the regional level (County Governor) as good; however, they think that the County Governor has little ability to act upon needs from below. Moreover, they think the regional level is controlled too much by the national level (Norwegian Environment Agency), and hence, they (municipality) cannot reach this level of management. They are looking for possible paths to reach the level of decision-making power and note that they have mobilized every channel possible at the local level in their attempts to achieve this. It is difficult to reach any further at the regional level according to the local government's representatives; thus, they need to reach the national level somehow but feel powerless, as they have not been able to accomplish this.

Both the interviewed pastoralists and the local government officials feel very frustrated over international treaties, such as the Bern Convention, that have such direct bearing on the local peoples' livelihoods. They felt relieved when the Carnivore Agreement (2011) was signed, but they now feel increasingly deceived as they have experienced that it is not implemented. One local agricultural extension officer expressed it this way:

The pastoralists are squeezed out from an area they are meant to have priority in according to the RCC's management plan. This is the reality because this management decision is not followed through, and this is hard to deal with. We work hard to obtain a clarification on this so that we can be sure if we have an area prioritized for pasturing, or if it is a disguised carnivore area (interview of local agricultural officer)

According to the local agricultural officers, mobilization is lacking at the regional level (County Governor) towards defending the pastoralists' case. They perceive the government's environmental side as powerful, with a strong focus on defending carnivores. Meanwhile, they perceive the agricultural department at the regional level as less visible and not fronting the pastoralists enough. As a response to the lack of mobilization, the local government invited pastoralists, the agricultural department at the County Governor's Office and the Norwegian Food Safety Authority to an ad hoc meeting to discuss the carnivore-pastoralism issue and to find some answers to what the herders themselves can do, and what the County Governor is willing to do to assist the pastoralists in their struggle against carnivores. They omitted inviting the environmental department at the County Governor's Offices and the State Nature Inspectorate, as they wanted to avoid a discussion on carnivore politics. Little progress was seen during this meeting, as the County Governor's representatives focused on the potential of changing to alternative income activities for the farmers that would not be sensitive to carnivores. Such discussions met neither the pastoralists' nor the local governments' wishes for future pastoralism.

\section{Representation in RCC meetings}

Actors from the agricultural sector and from environmental organizations and sectors do not assemble at the local and regional levels, according to government officials and representatives in the RCC. Meetings held by the RCC are open and with possibilities for any interest groups to join and come with utterances. Although actors from local farmers' organizations always attend the RCC meetings, the environmental side perceive the representatives in the RCC to take pastoralists' interests too much into account when managing carnivores. Relatively few environmental groups are very active in the studied region, and none of the local environmental groups attend the RCC meetings because they consider them futile and not considering carnivore dynamics at all. A representative from the most active environmental group noted that they choose instead to give written submissions to national-level planning processes, as they feel that the two-fold aim stated in the Carnivore Agreement is not taken seriously in the RCC. They also use the media when they wish to present a case. A representative from the RCC did not perceive the RCC meetings as a particularly suitable arena for environmental organizations to attend, as he noted that the agenda is mostly directed towards pastoralists, for instance, allocating money towards various incentives and regarding 
grazing matters. Conversely, the County Governor has tried to recruit people from environmental organizations to the meetings. A government official at the County level noted that it would be very useful if actors representing environmental aspects would be present at RCC meetings, as they could convey knowledge about carnivore biology and ecosystem dynamics. The official noted that the RCC would benefit from hearing both sides regarding a matter. In the meetings, they acquire the pastoralists' perceptions and needs orally across the table, while they receive written complaints from environmental actors after the meetings.

A representative from NNI noted that they have good communication with most pastoralists and local and regional government agencies. The NNI representative perceived the contact with the RCC as minimal and noted that the RCC would rarely contact NNI, even in cases where it would be very relevant to do so.

\section{Discussion}

Introduction of domesticated herbivores into mountain "wilderness" often is accompanied by ecosystem modifications either by herding one's flock and fencing off carnivores or by eradicating the same carnivores and thereby reducing the complexity of the ecosystem. In many instances, such a simplified carnivore-free cultural landscape of mountain pastures was created in northern Scandinavia between 1700 and 1960, and many of the governance conflicts, such as the one reported in this paper, are due to poorly connected government policies after 1960, the effort to reach a win-win solution: the policy of recreating the biodiverse wilderness on the one hand and the policy of a continued modernization of the pastural industry on the other hand. The state government fragmentation in Norway (NOU 2003: 19) becomes apparent in the governance system of the regional socialecological system, with biodiversity conservation on the one side through the environmental department and pastoral industry rationalization through the agricultural department on the other.

\section{Conflict alleviation - masking a commons dilemma}

Trade-offs appear through the mismatches between governance systems and the changing dynamics of the ecological system following the implementation of international conventions for carnivore protection. However, what appears to be a conflict between groups (pastoralists and environmentalists) is actually a set of new temporal and spatial interactions that are not fully addressed in the multi-level governance system. The government attempted to reconcile the interests of conservation and local users by decentralizing management authority of this complex dilemma to the regional level. However, this process has proved very challenging, as the management instruments that the regional authority devised to reduce the tension have inbuilt contradictions that created mismatches between governance and ecosystem dynamics in the SES. The focus on winwin solutions implemented through political policy instruments such as the Carnivore Agreement (2011) blurs the complex dynamics between biophysical characteristics and local culture and livelihoods. For instance, carnivore management instruments do not adequately account for the complexity of the pasture dynamics of the carnivorecultural landscape. More specifically, zoning maps are insensitive to the spatial dynamics of carnivore populations, and compensation schemes are not designed to prevent the increasing predation on domestic animals. The RCC's neglect of the carnivores' spatial behaviour when producing the zoning maps is a clear reflection of the mismatch between governance and the ecosystem dynamics. Even if carnivores' physical environment was considered in the management plan, producing zones with sharp borders is still a very difficult task due to carnivores' dispersal potential (Linnell et al. 2005). It is particularly relevant to scale management zones of carnivores in terms of much bigger land areas when compared to any other terrestrial species groups, as carnivores utilize large areas of land (Linnell et al. 2005). And for Nordland, it is particularly difficult to succeed with zoning due to the geography with a long and narrow stretch of land that borders Sweden with other policy choices related to carnivores.

The hunting incentives implemented are rigid due to state regulation. The local effect of culling lynx when losing sheep is only very temporary in areas where lynx are present, as the available home range soon will be replaced by new lynx (Odden et al. 2014), as discussed already. The compensation schemes introduced are different from Sweden's, where incentives and money are given for every documented carnivore, unlike in Norway where we compensate for livestock loss. In Sweden, pastoralists must accept predation to a larger degree on their livestock in exchange for economic compensation (see Swenson and Andrén 2005 for an in-depth comparison of the two countries' compensation schemes).

\section{Interactions in pastoral governance}

The complex dynamics between biophysical characteristics and local culture and livelihoods are not being addressed by dialogue between groups, and the divergence between interest groups is further exacerbated as mistrust between actors at different levels persists, and actor groups feel they need to defend and protect their practices. Hence, decentralization and deliberation of areas of responsibility do not reduce conflict between different user groups; rather, it shifts management focus from a strong emphasis on ecosystems to a more landproduction focus through the RCC, thereby maintaining the mismatch between contradicting interests through 
governance on the one hand and the biophysical system on the other.

Scientific ecological knowledge is made available through websites such as "Rovdata", but this information is insufficiently integrated into carnivore management at the local level. The RCC offers opportunities for interaction between different user interests by keeping the meetings open for the public to attend. Hence, as was the government's intention, these meetings have the potential of being a conflict-minimizing arena in which different stakeholders can interact, communicate and learn from each other (Ostrom 2007b). However, actors utilize different governance levels to seek influence and push their objectives, and an asymmetry seems apparent in the RCC meetings, whereby the RCC lacks legitimacy with environmental actors. This is reflected in the RCC meetings where only pastoralists and their organizations attend. The one-sided participation in the RCC meetings is an indication that this meeting arena is not a fruitful setting at this stage for interaction between user groups. Looking beyond the RCC, ambiguity from the national level about how to really deal with the complexities of carnivore governance propagates downward in the system and creates distrust across levels and scales. The outlook is different from the perspective of pastoralists and local government officials. They do not feel that their voice is being heard in government, and they feel powerless against a strong environmental department, while running the daily risk of losing animals to carnivores. This is reflected in the local government official's concern about the lack of predictability for the pastoralists who feel uncertain whether their pasture land is prioritized for grazing animals or for carnivores. The present area zoning is perceived as unrealistic at both local and regional levels, as actors know that carnivores roam vast areas and do not "stick" to administrative maps.

RCCs are potential arenas where trade-offs can be jointly mapped and understood. However, representatives of biodiversity conservation do not attend RCC meetings and use a blocking strategy to measures proposed by the RCCs, which are currently dominated by farmers' representatives. This leads to greater rigidity and inability for the system to respond to changes.

\section{Adaptive steps and measures}

Although pastoralists have tried out several measures to combat livestock losses, resistance exists, as they feel restricted from utilizing the pasture areas where they traditionally have had access. However, certain pastoralists have found ways forward to respond to the threat the carnivores entail. The reindeer herding district that tends their herd closely throughout winter has experienced fewer reindeer losses (see also Risvoll 2015). They have calm animals due to frequent stock handling with carefully selected husbandry methods; thus, tending and moving their herd when needed is also more manageable. However, this strategy comes with a price, as it is difficult to carry off with limited number of herders available, and other chores must then be placed on hold, for instance, participation in various meetings and boards. Sheep farmers who have traditional Norwegian breeds that tend to stay more in flocks have experienced declined losses to carnivores, to a certain extent. However, trade-offs exist, as income will be limited as long as the incentives favour heavy lambs (e.g. Risvoll 2015).

\section{Shifting to a trade-off policy narrative}

It is clear from our results that the two-fold policy aim - conservation of both biodiversity and cultural landscape - creates a dilemma. The current responses by the government and the multiple actors involved mask the trade-offs that emerge through complex interactions between ecological dynamics, user practices and stakeholder's interests and behaviour.

The instruments of implementation include large carnivore management, through zoning of the region separating areas for carnivores and for grazing, hunting schemes, compensation for loss of animals and incentives for implementation of new husbandry techniques or for transforming the sheep-farming practice towards other farming alternatives.

These instruments seem to roll out from a "palliative approach" that strives to cater to both broad objectives but fall short in reconciling stakeholders' interests. On the one hand, environmentalists resort to media and national government and do not feel the need to join the locally decentralized decision boards (RCC). On the other hand, we observed a reduced adaptive capacity of farmers that likely stems from their perception of being "squeezed out" and left with no feasible alternatives.

As a way forward, we speculate that the two-fold policy objectives need to explicitly acknowledge the ecological dynamics in order to unlock the current situation. This includes shifting to a policy narrative of local trade-offs rather than top-down, win-win narratives. In other words, revealing the inherent trade-offs might open up for innovative encounters/arenas and solutions in the governance sphere and in local communities' practices.

\section{Conclusion}

Trade-offs are inherent dynamics in complex socialecological systems. The interdependence we observe in northern Norway between policy objectives of biodiversity and cultural landscape conservation generates dilemmas that are not simple to reconcile. Our case study in northern Norway demonstrates how ecological dynamics 
among large carnivores, sheep and reindeer, mediated by mountain pasture and pastoralist practices, create interdependences in the social-ecological system that need to be considered when seeking to fulfil broad objectives of conserving biodiversity and ensuring viable local livelihoods. We found that trade-offs within the regional socialecological system are currently not directly addressed. Instead, the Carnivore Agreement, signed by all political parties at the national level, assumes that a two-fold aim can be pursued. Instead of solving the collective dilemmas, such mechanisms lead to social and ecological processes that render local communities and the pastoral sector vulnerable, and neither cultural diversity nor biodiversity prosper under the governance regime that is present today.

This case provides evidence for the importance of designing mechanisms to reach environmental objectives with attention to the trade-off dynamics and, specifically in this case, a need to attend to ecological dynamics. Making trade-offs explicit and salient to policymakers (including the ecological dynamics that can be covered by symbolic battles) is essential in the search for innovative synergies and can open up for a broader appreciation of the positive and negative effects of conservation.

\section{Endnotes}

${ }^{1}$ The number of sheep farmers has almost declined by 50 \% from 1995 to 2014 in the Salten Region, while sheep numbers in the same area are approximately the same (Norwegian Agriculture Agency 2014).

\section{Competing interests}

The authors declare that they have no competing interests.

\section{Authors' contributions}

Empirical studies for this article were conducted primarily by CR. GEF participated in some of the data collection. Analysis of the research material was a joint effort of CR, GEF and DG. CR drafted the first manuscript. GEF and DG reviewed the manuscript draft and provided inputs for its improvement. All the authors read and made comments that improved the final manuscript. All authors read and approved the final manuscript.

\section{Authors' information}

The authors of this manuscript have different backgrounds. Camilla Risvoll has recently defended her PhD in Sociology at the University of Nordland, and now works at Nordland Research Institute. Gunn Elin Fedreheim has a $\mathrm{PhD}$ in sociology focusing on nature-based tourism in protected areas and has a master's degree in political science. Diego Galafassi works on a PhD at Stockholm Resilience Centre. The thesis work explores how transformations can be studied from a social-ecological network perspective. He has a MSc on Environmental Science from Bologna University and a MSC at the Stockholm Resilience Centre looking at urban regional planning in Urban Stockholm Region from a network perspective.

\section{Acknowledgements}

DG was partially supported by the Strategic Research Programme EkoKlim at Stockholm University.

\section{Author details}

${ }^{1}$ Faculty of Social Sciences, University of Nordland/ Nordland Research Institute, Universitetsaleen 11, Mail Box 1490, 8049 Bodø, Norway. ${ }^{2}$ Harstad University College, Havnegata 5, Mail Box 1063, 9480 Harstad, Norway.
${ }^{3}$ Stockholm Resilience Centre/Stockholm University, Kräftriket 2B, SE-114 19 Stockholm, Sweden.

Received: 21 August 2015 Accepted: 11 January 2016

Published online: 08 February 2016

\section{References}

Agreement, Carnivore. 2011. Representantforslag 1635 (2010-2011). https://www.stortinget.no/Global/pdf/Representantforslag/2010-2011/ dok8-201011-163.pdf.

Aligica, P.D. 2014. Institutional diversity and political economy. The Ostroms and beyond. Oxford, UK: Oxford University Press.

Berg, B. A. (2000) Mot en korporativ reindrift. Samisk reindrift I det 20. århundre eksemplifisert gjennom studier av reindriften på Helgeland, Ph.D Thesis, (March 1999), University of Tromsø. Diedut: 3/2000, Guovdageaidnu/ Kautokeino: Sámi Instituhtta.

Berg, B.A., T. Arntsen, G. Fors, M.I. Hætta, and B. Aarseth. 2003. Samisk kulturkunnskap/Sámi kulturoahppu, lærebok for samisk videregående skole i norsk og samisk utgave (hovedforfatter). Oslo: Vett \& Viten AS.

Bjørkhaug, H., and K. Rønningen. 2013. Crisis? What crisis? Marginal farming, rural communities and climate robustness: The case of northern Norway. The International Journal of Sociology of Agriculture and Food 1(21): 51-69.

Bjørklund, I. 2013. Domestication, reindeer husbandry and the development of Sámi pastoralism. Acta Borealia 30(2): 174-189.

Blekesaune, A. and E.P. Stræte 1997. Rovviltdiskursen. En analyse av ideologisk baserte konfliktlinjer. Rapport 6/97, Senter for bygdeforskning.

Brown, K., N. Adger, E. Tompkins, P. Bacon, D. Shim, and K. Young. 2001. Trade-off analysis for marine protected area management. Ecological Economics 37(3): 417-434

Butchart, S.H.M., M. Walpole, B. Collen, and A. Van Strien. 2010. Global biodiversity: Indicators of recent declines. Science. doi:10.1126/science.1186777.

Chapron, G, P Kaczensky, JDC Linnell, M von Arx, D Huber, H Andrén, JV López-Bao, M Adamec, F Álvares, O Anders, L Balčiauskas, V Balys, P Bedő, F Bego, JC Blanco, U Breitenmoser, H Brøseth, L Bufka, R Bunikyte, P. Ciucci, A Dutsov, T Engleder, C Fuxjäger, C Groff, K Holmala, B Hoxha, Y lliopoulos, O lonescu, J Jeremić, K Jerina, G Kluth, F Knauer, I Kojola, I Kos, M Krofel, J Kubala, S Kunovac, J Kusak, M Kutal, O Liberg, A Majić, P Männil, R Manz, E Marboutin, F Marucco, D Melovski, K Mersini, Y Mertzanis, RW Mysłajek, S Nowak, J Odden, J Ozolins, G Palomero, M Paunović, J Persson, H Potočnik, P-Y Quenette, G Rauer, I Reinhardt, R Rigg, A Ryser, V Salvatori, T Skrbinšek, A Stojanov, JE Swenson, L Szemethy, A Trajçe, E Tsingarska-Sedefcheva, M Váňa, R Veeroja, P Wabakken, M Wölfl, S Wölfl, F Zimmermann, D Zlatanova, and L Boitani. 2014. Recovery of large carnivores in Europe's modern human-dominated landscapes. Science 346(6216).

County Governor, Nordland, Agricultural Division. 2014. Reindrift.

Daw, T.M., S. Coulthard, W.W.L. Cheung, K. Brown, C. Abunge, D. Galafassi, G.D. Peterson, T.R. McClanahanh, J.O. Omukoto, and L. Munyi. 2015. Evaluating taboo trade-offs in ecosystems services and human well-being. Proceedings of the National Academy of Sciences (PNAS) 112(22): 6949-6954.

Directorate for Nature Management. 2011. Færre rovviltskader på sau. http://www.miljodirektoratet.no/no/Nyheter/Nyheter/Nyhetsarkiv/2008/12/ Farre-rovviltskader-pa-sau/. Accessed 16 March 2013.

Eilertsen, SM. 2008. Radiobjeller på rein. [Presentation at the seminar Vernede områder som verdiskapingsressurs 02/17/09 in Bodø, Norway].

Fangel, K and V Gundersen, 2012. Rovviltforvaltningen i et planteoretisk perspektiv. Utmark- tidsskrift for utmarksforvaltning, Nr. 1.

Fedreheim, G.E. 2013. Value creation on Norway's green gold. An analysis of policy formulation and implementation in the field of nature conservation. PhD Thesis. Sociology. Bodø: University of Nordland.

Gangaas, K.E., B.P. Kaltenborn, and H.P. Andreassen. 2013. Geo-spatial aspects of acceptance of illegal hunting of large carnivores in Scandinavia. PLOS ONE 8(7): e68849. http://journals.plos.org/plosone/article?id=10.1371/journal.pone.0068849.

Heikkinen, H., O. Moilanen, M. Nuttall, and S. Sarkki. 2011. Managing predators, managing reindeer: contested conceptions of predator policies in Finland's southeast reindeer herding area. Polar Record 47(242): 218-230.

Heikkinen, H.I., S. Sarkki, and M. Nuttal. 2012. Users or producers of ecosystem services? A scenario exercise for integrating conservation and reindeer herding in northeast Finland. Research, Policy and Practice 2012(2): 11. http://www.pastoralismjournal.com/content/2/1/11.

Howe, C., H. Suich, B. Vira, and G.M. Mace. 2014. Creating win-wins from tradeoffs? Ecosystem services for human well-being: A meta-analysis of ecosystem 
service trade-offs and synergies in the real world. Global Environmental Change 28: 263-275.

Ingold T. (1980) Hunters, pastoralists and ranchers: reindeer economies and their transformations. Cambridge: Cambridge University Press.

Jaren, V., and J.P. Løvstad (eds.). 2001. Delrapport 3 fra forskningsprogrammet bruk og forvaltning av utmark, 49-60. Oslo: Norges forskningsråd.

Kristoffersen, M. 2015. Alt du trenger å vite om jordbruksoppgjøret. Nationen. Oslo: National Newspaper. 24 April 2015.

Landbruksdirektoratet 2014. Behovet for arealer. http://www.reindrift.no/ ?id=974\&subid=0. Accessed 9 December 2014.

Linnell, J.D.C., E.B. Nilsen, U.S. Lande, I. Herfindal, J. Odden, K. Skogen, R. Andersen and U. Breitenmoser. 2005. Zoning as a means of mitigating conflicts with large carnivores: Principles and reality. In People and wildlife - conflict or coexistence? ed. R. Woodroffe, S. Thirgood, and A. Rabinowitz. London: Cambridge University Press.

LOV-1981-05-29 nr 38. 1981. Wildlife Act. Oslo: Ministry of Climate and Environment.

LOV-2014-06-20-50. 2014. Nature Diversity Act. Oslo: Ministry of Climate and Environment.

LOV-1972-06-09-31. 1972. Reindeer Herding Act. Oslo: Ministry of Agriculture and Food.

McShane, T.O., P.D. Hirsch, T.C. Trung, A.N. Songorwa, A. Kinzig, B. Monteferri, D. Mutekanga, H.V. Thang, J.L. Dammert, M. Pulgar-Vidal, M. Welch-Devine, J.P. Brosius, P. Coppolillo, and S. O'Connor. 2011. Hard choices: Making trade-offs between biodiversity conservation and human well-being. Biological Conservation 144: 966-972.

Naturvårdsverket. 2015. Revidera förvaltningsplaner

Norwegian Agriculture Agency. 2014. Production subsidy - archive. http:// statistikk.landbruksdirektoratet.no/skf/prodrapp.htm. Accessed 13 March 2014

Norwegian Environment Agency. 2014. Norway helps preserve European biodiversity. http://www.miljodirektoratet.no/en/News1/2015/Norway-helpspreserve-European-biodiversity/. Accessed 23 March 2014

NOU 2003: 19. 2003. Makt og demokrati. Oslo. https://www.regjeringen.no/no/ dokumenter/nou-2003-019/id118893/. Accessed: 08 Jan 2015.

NRK Nordland. 2010. Bort med bamse. http://www.nrk.no/nordland/bort-medbamse-1.7221893 Accessed 14 April 2013.

Odden, J., J. Mattisson, V. Gervasi, and og.J. Linnell. 2014. Gaupas predasjon på sau - en kunnskapsoversikt. - NINA Temahefte 57. Trondheim: Norsk Institutt for naturforskning.

Ostrom, E. 2005. Understanding institutional diversity. Princeton: Princeton University Press.

Ostrom, E. 2007a. A diagnostic approach for going beyond panaceas. PNAS 104(39): 15181-15187.

Ostrom, E. 2007b. Sustainable social-ecological systems: An impossibility? Paper presented at American Associations for the Advancement of Science Conferences, San Francisco, 15-19 February 2007.

Ostrom, E. 2009. A general framework for analyzing sustainability of socialecological systems. Science 325(5939): 419-422. http://dx.doi.org/10.1126/ science.1172133.

Parliament's Document Nr. 8:163 S (2010-2011). Representantforslag 163 S. Til Stortinget (parliament). https://www.stortinget.no/no/Saker-og-publikasjoner/ Publikasjoner/ Representantforslag/.

Plummer, R., and D. Armitage. 2010. Adaptive capacity and environmental governance. Berlin, Heidelberg, Canada: Springer.

Reindeer Herding Website 2015. A virtual guide to reindeer and the people who herd them. Sami \& Finns - Finland, history. www.reindeerherding.org 2015. Accessed 07.02.2015.

Reindriftkonvensjonen. 2010. Konvensjonen mellom Norge og Sverige om grenseoverskridende reindrift. Den norske og den svenske regjering. http://www.regjeringen.no/upload/LMD/Nedlegg/Regelverk/Reindrift_ konvensjon_Norge_Sverige_260209.pdf

Risvoll, C. 2015. Adaptive capacity and adaptation processes within pastoral communities in the face of environmental and societal change. Ph.D Thesis. Bodø: University of Nordland.

Risvoll, C., G.E. Fedreheim, A. Sandberg, and S. BurnSilver. 2014. Does pastoralists' participation in the management of national parks in northern Norway contribute to adaptive governance? Ecology and Society 19(2): 71

Rockström, J., W. Steffen, K. Noone, A. Persson, F.A. Chapin, E.F. Lambin, T.M. Lenton, M. Scheffer, C. Folke, H.J. Schellnhuber, B. Nykvist, C.A. de Wit, T. Hughes, S. van der Leeuw, H. Rodhe, S. Sorlin, P.K. Snyder, R. Costanza, U. Svedin, M. Falkenmark, L. Karlberg, R.W. Corell, V.J. Fabry, J. Hansen, B. Walker,
D. Liverman, K. Richardson, P. Crutzen, and J.A. Foley. 2009. A safe operating space for humanity. Nature 461: 472-475.

Rodríguez, J.P., T.D. Beard Jr., E.M. Bennett, G.S. Cumming, S. Cork, J. Agard, A.P. Dobson, and G.D. Peterson. 2006. Trade-offs across space, time, and ecosystem services. 2014. Ecology and Society 11(1): 28.

Sandberg, A. 1999. Conditions for community-based governance of biodiversity, NF-report (11/99). Bodø: Nordlandsforskning.

Sande, A. 2010. Villmark i grenseland: Samenes hjemland, nasjonalpark eller verdensarvområdet Laponia? Oslo: Unipub.

Skogen, K. 2014. Utilsiktede konsekvenser I rovviltforvaltningen. Utmark - tidsskrift for utmarksforskning. Nummer $1 \& 2$

Skogen, K., and C. Thrane. 2008. Wolves in context: using survey data to situate attitudes within a wider cultural framework. Society \& Natural Resources 21: 17-33.

Skogseid, H. 1997. Reindrift i Salten - Beitestrategier i utmarka under naturlige forstyrrelser. NF-rapport 1024, Nordlandsforskning.

Skuland, S.E., and K. Skogen. 2014. Rovdyr i menneskenes landskap. Utmark tidsskrift for utmarksforskning. Nummer $1 \& 2$.

Stortinget 2010-2011 (2011) Parliament's Document Nr. 8:163 S. (2010-2011) Representantforslag 163 S. [online] https://www.stortinget.no/no/Sakerog-publikasjoner/Publikasjoner/ Representantforslag/. Accessed: 12.10.2014

St.meld.nr. 27 (1991-1992). 1991. Forvaltning av bjørn, jerv, ulv og gaupe. Oslo: Ministry of Climate and Environment.

St.meld.nr. 35 (1996-1997). 1996. Om rovviltforvaltning. Oslo: Ministry of Climate and Environment.

St.meld.nr.15 (2003-2004). 2003. Rovvilt i norsk natur. Oslo: Ministry of Climate and Environment.

Swenson, JE and H Andrén. 2005. A tale of two countries: large carnivores depredation and compensation schemes in Sweden and Norway. In People and wildlife: conflict or coexistence? ed. Woodroffe, R, S Thirgood, and A Rabinowitz. Conservation Biology 9. Cambridge: Cambridge University Press, the Zoological Society of London.

Swenson, JE and J Kindberg. 2011. Arealkrav til en hunnbjørnbestand med 20 ynglinger årlig i Norge. Rapport nr. 2011-2, Det skandinaviske bjørneprosjektet til Direktoratet fro naturforvaltning.

Swenson, JE, O-G Støen, A Zedrosser, J Kindberg, S Brunberg, JM Arnemo and V Sahlèn. 2010. Bjørnens status og økologi i Skandinavia. Rapport 2010 - 3 fra Det skandinaviske bjørneprosjektet til Miljøverndepartementet.

Trondsen, M. 06.08.2015. Liker dårlig at sauene må hentes ned fra beite, Saltenposten (local newspaper), Fauske.

Våg, T. and L. E. Wallin. (2015) Beitesesongen 2015, Norsk Sau og Geit. Ås. 29.07. 2015. Accessed 02.08.2015: http://http://www.nsg.no/forsiden/uttale-omarets-beitesesong-article9503-364.html.

Vorren, Ø. 1978. Bosetning og ressursutnytting under veidekulturen og dens differensiering. Finnmarksvidda Natur-kultur, NOU 18A. Oslo: Statens forvaltningstjeneste.

Young, J., A. Watt, P. Nowicki, D. ALard, J. Clitherow, K. Henle, R. Johnson, E. Laczko, D. McCracken, S. Matouch, J. Niemela, and C. Richards. 2005. Towards sustainable land use: Identifying and managing the conflicts between human activities and biodiversity conservation in Europe. Biodiversity \& Conservation 14(7): 1641-1661.

Young, J.C., M. Marzano, R.M. White, D.I. McCracken, S.M. Redpath, D.N. Carss, C.P. Quine, and A.D. Watt. 2010. The emergence of biodiversity conflicts from biodiversity impacts: Characteristics and management strategies. Biodiversity Conservation 19: 3973-3990.

\section{Submit your manuscript to a SpringerOpen ${ }^{\circ}$ journal and benefit from:}

- Convenient online submission

- Rigorous peer review

- Immediate publication on acceptance

- Open access: articles freely available online

- High visibility within the field

- Retaining the copyright to your article

Submit your next manuscript at $\boldsymbol{s p r i n g e r o p e n . c o m ~}$ 